be favourable compared with that of natural fats, and would almost certainly approach that of fatty acids from petroleum which presumably do not offer an attractive commercial proposition, since no company has yet undertaken the process.

I would suggest that synthetic detergents will command a share of the detergent market which will depend on their efficiency and price. To that extent they will relieve the requirements for oils and fats of the detergent industry. Meanwhile, until we have exhausted the possibility of providing oils and fats themselves, I would suggest that no useful purpose is served by forcing something on the housewife which she may not want, and which can in any case only be produced by erecting a vast amount of new plant and equipment to produce oils and fats at apparently uneconomic prices.

\title{
REFERENCE
}

Fuggles-Couchman, N. R. (1950). Brit. Y. Nutrit. 4, 74.

\section{Sugar and Food Yeast}

\section{By P. LyLe, Plantation House, Mincing Lane, London, E.C. 3}

This morning, Dr Wiggins (1950) gave a comprehensive survey of the position of the sugar industry in the West Indies and I propose to amplify some of his remarks.

I happen to be connected with two companies owning sugar estates and sugar factories in Jamaica and Trinidad, and we are necessarily much concerned with the welfare and nutrition of the local populations which are increasing at an alarming rate. For instance, the population of Jamaica will, at the present rate, double itself in 35 years.

Sugar is the main crop in most of the islands, and increased production is of the greatest importance. More employment can be given when the increased production is the result of bringing new land into cultivation, but it is a fact that a great part of the increased production is caused by increases in yields of sugar per acre resulting from improved and mechanized cultivation, pest and weed control, and field trials of varieties and of manures, which are carried out on a large scale.

Increased production of sugar cannot alone do all that is required to feed the people, and we have to look for other methods, particularly in view of the fact that these islands, primarily agricultural, import large quantities of meat, milk and other foodstuffs from outside. One example of what is being attempted may be mentioned. In Barbados, where large quantities of condensed milk are imported, many of the sugar-cane estates are building up dairy herds. Fodder is plentiful in the wet season and cane tops can be used during the cutting of the cane crop; for the short period between the cane crop and the return of green fodder after the onset of the rains, making of silage is being developed.

In the peasant agriculture, most of the holdings are very small and worked by the 
family; the encouragement of better and more intensive cultivation is being energetically undertaken by the Department of Agriculture, which has established six district stations running demonstration holdings of ro-20 acres. Some useful rotations have been developed in conjunction with sugar-cane, which is of course the main cash crop, others being maize, cotton, cow peas, yams, sweet potatoes and tomatoes. In addition, a small area of irrigated fodder, usually Guatemala grass, is grown, so that besides vegetables for human consumption there are crop residues, cane tops during harvest, silage and irrigated grasses, which allow animals to be kept, with milk and meat for the peasant, and pen manure for the land; in fact all the benefits of mixed farming are obtained.

I would like now to refer to another venture in which I happen to be interested myself and which was mentioned by Dr Wiggins this morning, namely food yeast, developed by the Germans in the first world war. At the beginning of the last war the subject was taken up again at the Microbiological Department at Teddington by Dr A. C. Thaysen, who successfully developed a method of production of Torula yeast on a pilot-plant scale. 'This yeast contains nearly $50 \%$ protein and is rich in the vitamin B complex and should thus be a valuable addition to the diets of colonial peoples, which consist chiefly of starchy foods. The Colonial Office decided to erect a plant for the production of Torula yeast in the West Indies and came to an agreement with our Jamaica company, by which we built the necessary plant to work in conjunction with one of our sugar factories where steam and power and the necessary raw material, molasses, were readily available. We have already successfully produced considerable quantities of good food yeast, but unfortunately the Colonial Office has found the distribution of the product to the people who most need it an extremely difficult proposition. Although the product is palatable to many people, it is by no means so to all, and it is extremely difficult to persuade a West Indian to eat something just because he is told that it is good for him. The only solution seems to be to incorporate the yeast in some other food, but that already hard-worked vehicle, flour, is out of the question, and no other way has yet been discovered. In my opinion the solution will ultimately be found in producing a different and more palatable yeast. Already several are being tested and an interesting newcomer was reported from Stockholm the other day by $\mathrm{Dr}$ H. Lundin (1949), called Rhodotorula gracilis, a yeast containing $23 \%$ protein and $42 \%$ fat, but its commercial possibilities are as yet unknown. Much research work still remains to be done, but from our experience so far, and with an eye on the future when the problem of feeding the world population becomes acute, the possible contribution which may be made by food yeast is worth considering. Sugar-cane, being a grass which is ploughed up and replanted every $3^{-4}$ years, can be grown continuously on the same land without rotation with other crops. On our Jamaica estates, the average yield of available sugar, which is gradually increasing as improved varieties and methods are introduced, is about 3.5 tons/acre.

The animal acts as a factory for the conversion of vegetable protein into high-value protein, but is a rather inefficient factory. To make a comparison between the two methods is extremely difficult owing to the complexity of farming operations, but the following figures give some idea of the order of the difference. If food yeast were made 
directly from the cane juice the yield of dried yeast should be about $3300 \mathrm{lb}$./acre, equivalent to about $1500 \mathrm{lb}$. digestible protein. Taking fat cattle at I $100 \mathrm{lb}$. live weight, of which II \% is digestible protein, twelve and a half head of cattle are needed to give $1500 \mathrm{lb}$. protein. Hence the potential digestible protein production from $\mathrm{I}$ acre of sugar-cane is equivalent to the production from twelve and a half head of 2-year-old cattle slaughtered annually. For the maintenance and production of twenty-five head of cattle on the land the equivalent of 25 acres of good pasture would be required.

\section{REFERENCES}

Lundin, H. (1949). Chem. \& Ind. p. 872.

Wiggins, L. F. (1950). Brit. F. Nutrit. 4, 69. 